\title{
Wspomnienia Wincentego
} Mossakowskiego z lat 1914-1926. Młodzieżowa działalność społeczno-patriotyczna oraz nauka w Seminarium Nauczycielskim w Pułtusku

Artykuł zawiera wspomnienia Wincentego Mossakowskiego, mieszkańca podpułtuskiej wsi Gromin, z okresu pierwszych dekad XX w. Takie wspomnienia nieczęsto są przedmiotem wydawnictw źródłowych. Zdaniem autora artykułu takie relacje w sposób istotny wzbogacają wiedzę o dziejach małych ojczyzn, szczególnie wtedy, gdy dotyczą trudnych okresów historycznych. Warto dodać, że w tym przypadku wzbogacają również wiedzę o historii Mazowsza.

Słowa kluczowe: Gromin, Pułtusk, edukacja, niepodległość, seminarium nauczycielskie, Polska Organizacja Wojskowa

Wspomnienia „zwykłych” mieszkańców polskiej wsi z pierwszych dekad XX w. rzadko bywają przedmiotem wydawnictw źródłowych. Składa się na ten stan rzeczy kilka przyczyn, wśród których wymienić można stosunkowo niewielką liczbę powstałych i zachowanych relacji, niską kulturę pisarską tekstów, ogra- 


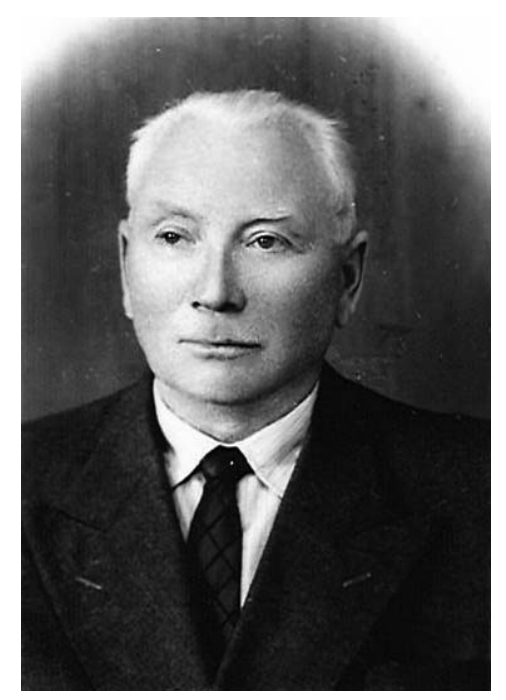

Fot. 1. Wincenty Mossakowski, $1958 \mathrm{r}$.

Źródło: Biblioteka Pedagogiczna w Ciechanowie Filia w Pułtusku, Kronika Pedagogicznej Biblioteki Powiatowej w Pułtusku [rkps].

niczony zasięg opisywanych zdarzeń, niewielką (często pozornie!) wartość poznawczą i co za tym idzie - atrakcyjność dla potencjalnych wydawców. W naszym przekonaniu są one bardzo ważne, pozwalają bowiem na podejmowanie badań z zakresu mikrohistorii: funkcjonowania danego środowiska, społeczności, miejsca.

Autor publikowanej poniżej relacji - Wincenty Mossakowski (1899-1980) ${ }^{1}$ - pochodził z chłopskiej rodziny mieszkającej w podpułtuskiej wsi Gromin. Miejscowość ta położona jest ok. $6 \mathrm{~km}$ na północny zachód od Pułtuska, przy drodze do Ciechanowa. Jego rodzice Paweł i Rozalia z Godlewskich posiadali niewielkie gospodarstwo (10 ha), z którego utrzymywali dosyć liczną rodzinę składającą się z sześciorga dzieci. Jeszcze przed wybuchem I wojny światowej Wincenty skończył szkołę początkową. W czasie wojny zaangażował się w działalność społeczno-patriotyczną: wstąpił wraz z kolegami do Polskiej Organizacji Wojskowej, był jednym z założycieli i pierwszym prezesem Koła Młodzieży Wiejskiej im. Tadeusza Kościuszki w Grominie ${ }^{2}$.

W 1918 r. rozpoczął naukę w Seminarium Nauczycielskim w Pułtusku. Był świadkiem rozbrajania niemieckiego garnizonu Pułtuska i eskortował niemieckich żołnierzy do stacji kolejowej w Ciechanowie. Po wydarzeniach tych przerwał naukę i wstąpił do rodzącego się Wojska Polskiego, w którym służył do 11 listopada 1921 r. Po urlopowaniu z wojska powrócił do nauki w Seminarium Nauczycielskim, które ukończył w 1926 r. Został nauczycielem w Wólce Lubielskiej, następnie w Leszczydole Starym.

We wrześniu 1939 r. jako oficer rezerwy WP walczył w 13 pp pod Gruduskiem i w obronie Twierdzy Modlin. Po zwolnieniu z niewoli zaangażował się w tajne nauczanie $^{3}$ i działał w strukturach AK pod pseudonimem „Grom”. Tuż po wojnie

1 Wincenty Mossakowski urodził się 7 kwietnia 1899 r. w Grominie, zmarł 24 czerwca 1980 r. w Warszawie. Archiwum Państwowe w Warszawie Oddział w Pułtusku, Akta stanu cywilnego Parafii Rzymskokatolickiej w Przewodowie, Akt urodzenia nr 31/1899 r., sygn. 79/117/0/-/39; T. Kowalski, J. Młodyński, J. Szczepański, Wpisani w historię Pułtuska. Słownik biograficzny, Pułtusk 2001, s. 191-192.

2 Koło Młodzieży Wiejskiej im. Tadeusza Kościuszki powstało 15 października 1917 r., w setną rocznicę śmierci swojego patrona. W latach 1917-1918 działało w nim 46 dziewcząt i chłopców. Odżyja wspomnienia sprzed 50 lat..., „Trybuna Mazowiecka” 1967, nr 254.

3 W. Mossakowski był od 1927 r. kierownikiem szkoły w Leszczydole Starym pod Wyszkowem, pełnił tę funkcję również podczas okupacji, organizując tajne komplety. Z. Kiljan, Tajne nauczanie 
został aresztowany przez NKWD. W kolejnych latach pracował jako nauczyciel w Wyszkowie i Pułtusku. W 1956 r. powierzono mu misję zorganizowania Pedagogicznej Biblioteki Powiatowej w Pułtusku, a 1 stycznia 1918 r. został powołany na etatowego kierownika tej placówki ${ }^{4}$ Pozostał na tym stanowisku do emerytury.

Podstawą niniejszej edycji jest maszynopis składający się z dziewięciu numerowanych kart formatu A4, sygnowany odręcznym podpisem Autora. Egzemplarz znajduje się w zbiorach Edwarda Malinowskiego z Pułtuska, obecnie w pieczy jego spadkobierców. Tekst powstał pod koniec życia Wincentego Mossakowskiego, na przełomie wiosny i lata 1978 r., jednak mimo perspektywy czasowej sześciu dekad jest bardzo precyzyjny i wiarygodny. Relację znał i korzystał z niej Tadeusz Kowalski ${ }^{5}$. Nie była jednak nigdy publikowana w całości czy obszernych cytatach.

Pułtusk dnia 28 czerwca 1978 r.

\section{Na 60-lecie Preparandy, Seminarium Nauczycielskiego i rozbrojenia Niemców 1918 roku w Pułtusku Wspomnienia Wincentego Mossakowskiego, nauczyciela emeryta, zamieszkałego w Pułtusku}

Urodziłem się 7 kwietnia 1899 r. we wsi Gromin, pow. Pułtuski w zaborze rosyjskim. Ojciec Paweł, rolnik na 10 ha. Matka Rozalia z Godlewskich. Rodzeństwo: dwie siostry Maria i Zofia zamężne. Najstarszy brat Szczepan w 1913 r. żonaty z Marią Mączyńską przejął całe gospodarstwo rolne od rodziców, przy których było nas pozostałych troje z rodzeństwa, tj. brat Władysław, ja Wincenty i siostra Aleksandra ${ }^{6}$.

Dzieciństwo i młodość miałem bardzo trudne.

Rok 1914

W maju 1914 r. ukończyłem jednoklasową (trzyoddziałową) szkołę w Przewodowie, jedyną w gminie Kozłowo. Nauczycielem był pan Jan Rochmiński.

W tym czasie były dwa ugrupowania gospodarczo-polityczne: a) Trójprzymierze, tzn. państwa centralne, tj. Niemcy Austro-Węgry i Włochy; b) Trójporozumienie, tzw. Ententa, tj. Anglia, Francja i Rosja.

Antagonizmy pomiędzy tymi dwoma ugrupowaniami narastały, co doprowadziło do wojny. Bezpośrednim powodem wojny było zabójstwo austro-wę-

w latach okupacji, [w:] A. Gieysztor i in. (red.), Pułtusk. Studia i materiały z dziejów miasta i regionu, t. 2, Warszawa 1975, s. 273-274; T. Kowalski, Nauczyciele ziemi pułtuskiej w latach wojny i okupacji niemieckiej (1939-1945): część II, „Rocznik Mazowiecki” 2004, nr 16, s. 93-94.

$4 \quad$ Kronika Pedagogicznej Biblioteki Powiatowej w Pultusku, rok 1968.

5 T. Kowalski, Państwowe Seminarium Nauczycielskie w Puftusku w latach 1918-1938, [w:] H. Samsonowicz i in. (red.), Pułtusk. Studia i materiały z dziejów miasta i regionu, t. 5, Pułtusk 2003, s. 129-157.

6 Potomkowie Mossakowskich do dzisiaj mieszkają w Grominie. 
gierskiego następcy tronu, arcyksięcia Franciszka Ferdynanda dn. 28 czerwca 1914 r. w Sarajewie (Bośnia) należącym do Serbii. Austro-Węgry wystąpiły do Serbii z ultimatum. Serbia ultimatum odrzuciła. Pod naciskiem Niemiec Austro-Węgry wypowiedziały 28 lipca 1914 r. wojnę Serbii. Rosja stanęła w obronie Serbii.

1 sierpnia 1914 r. Niemcy wypowiedziały wojnę Rosji, a 3 sierpnia Francji. 4 sierpnia Niemcy wkroczyli na terytorium neutralnej Belgii, co spowodowało przystąpienie Anglii do Wojny z Niemcami.

23 sierpnia Japonia wypowiedziała wojnę Niemcom, a w listopadzie po stronie Niemiec wystąpiła Turcja. I tak się zaczęła pierwsza wojna światowa, która trwała od 1 sierpnia 1914 r. do 11 listopada $1918 \mathrm{r}$.

\section{Rok 1915}

23 maja Włochy wypowiedziały wojnę Austrii.

5 sierpnia 1915 r. wojska rosyjskie pod naporem Niemców opuściły Warszawę, wycofując się na Wschód. Od sierpnia 1915 r. do listopada 1918 r. znaleźliśmy się pod okupacją niemiecką. W październiku 1915 r. po stronie państw centralnych przystąpiła do wojny Bułgaria.

\section{Rok 1916}

Na terenie byłego zaboru rosyjskiego Niemcy pozwolili na organizowanie oświaty. To też powstawały szkoły po wioskach, w izbach wiejskich z braku odpowiednich pomieszczeń.

W Grominie w pierwszych dwóch latach (1915/16 i 1916/17 r. szk[olny]) szkoła mieściła się w jednej izbie u p. Stanisława Pika ${ }^{7}$ Uczył p. Modest Gałczyński, absolwent gimnazjum pułtuskiego, który obok nauki dziennej z dziećmi zorganizował kurs wieczorowy dla młodzieży oraz z chłopcami POW (Polską Organizację Wojskową) $)^{8}$. Zadaniem POW było przygotować młodzież do walki z okupantem. Szkolenia wojskowe odbywały się w lasach lub nocami. Po złożeniu przysięgi dn. 31 maja 1916 r. nadano mi pseudonim „Stwosz” i przyjęto do POW. Nauczycielowi M. Gałczyńskiemu w pracy społeczno-oświatowej z młodzieżą pomagali koledzy, uczniowie gimnazjum pułtuskiego: Franciszek i Wacław Słomińscy ${ }^{9}$, synowie lekarza ${ }^{10}$,

$7 \quad$ W organizację szkoły dla gromińskiej młodzieży zaangażowali się miejscowi gospodarze: Piotr Pańkowski, Stanisław Domżalski, Bronisław Iniarski, Walenty Łaszczych, Józef i Wincenty Arazy. Odżyjq wspomnienia sprzed 50 lat..., „Trybuna Mazowiecka” 1967, nr 245.

8 O działalności M. Gałczyńskiego: T. Kowalski, Nauczyciele i młodzież szkolna Pułtuska wobec walki narodu polskiego o niepodległość w latach 1914-1918, „Rocznik Mazowiecki” 2000, nr 12, s. 75.

$9 \quad$ Franciszek Feliks Słomiński (1897-1919) - syn lekarza, dowódca żandarmerii Komendy Obwodu Pułtusk POW. Kierował akcją rozbrajania Niemców w dniu 11 listopada 1918 r. i współdowodził atakiem na niemieckie starostwo. W 1919 r. wstąpił do Wojska Polskiego. Zginął w walkach z bolszewikami. Jego brat Wacław Wawrzyniec Słomiński ukończył chemię na Uniwersytecie Lwowskim.

10 Maciej Słomiński (1853-1914), w latach 1905-1913 lekarz powiatowy w Pułtusku i aktywny społecznik: prezes Ochotniczej Straży Pożarnej w Pułtusku i założyciel Pułtuskiego Towarzystwa Cyklistów. 
Roman Gutowski ${ }^{11}$ i Tałandziewicz ${ }^{12}$, synowie kier[owników] szkół ${ }^{13}$, Michał Chrupek $^{14}$, syn leśniczego i inni.

Przy takiej obsadzie uczyliśmy się historii Polski, śpiewu, odbywaliśmy próby teatralne, dawaliśmy przedstawienia amatorskie i organizowaliśmy zabawy taneczne. Przedstawienia urządzaliśmy w stodole w miesiącach maj-czerwiec. Przed widowiskiem i po odbywała się zabawa taneczna na powietrzu „Majówka”, która trwała do dnia następnego przy akompaniamencie śpiewu słowiczego. Bawiono się ochoczo bez alkoholu, a przygrywała kapela wiejska. Dekoracje scen wypożyczaliśmy z gimnazjum ${ }^{15}$. Za pieniądze zebrane za bilety wstępu na zabawę i przedstawienie zakupiliśmy książki ${ }^{16}$. I tak zapoczątkowano bibliotekę w Grominie, którą opiekował się p. Piotr Pańkowski.

27 sierpnia 1916 r. Rumunia przystąpiła do wojny po stronie Ententy.

Po ogłoszeniu aktu cesarzy Niemiec i Austrii z dn. 5 listopada 1916 r., tworzącego pseudoniezależne Królestwo Polskie z ziem byłego zabory rosyjskiego, Legiony Polskie zostały wycofane $\mathrm{z}$ frontu wschodniego i rozmieszczone po miastach byłej Kongresówki z zadaniem werbowania młodzieży do wojska. Jeden batalion 5 pp legionów przybył do koszar w Pułtusku ${ }^{17}$. Część taboru zakwaterowano w Grominie. Młodzi chłopcy legioniści chętnie przychodzili na nasze zebrania i zabawy wieczorowe ${ }^{18}$. Wesoło płynął czas.

${ }_{11}$ Roman Gutowski, syn nauczyciela, był wraz z dwoma braćmi współorganizatorem struktur POW w powiecie pułtuskim. Wszyscy trzej zginęli za ojczyznę: Henryk w 1917 r., Roman (major WP, dowódca III batalionu 54 pp) w 1939 r., Mieczysław (porucznik WP) w 1940 r. w Charkowie.

12 Zygmunt Tałandziewicz, syn nauczyciela, był współorganizatorem POW w powiecie pułtuskim, brał udział w wojnie polsko-bolszewickiej.

13 Ignacy Gutowski (1863-1940), ojciec Romana, był w latach 1918-1925 kierownikiem Publicznej Szkoły Powszechnej nr 1 im. św. Stanisława Kostki w Pułtusku. Jego następcą w okresie 19251934 był Antoni Tałandziewicz (1874-1944), ojciec Romana. A. Koseski, J. Szczepański (red.), Dzieje Puttuska, t. 2: 1795-1989, Pułtusk 2017, s. 297.

14 Michał Chrupek (1898-1944), syn leśniczego i dzierżawcy Sadykrza Rajmunda Chrupka, członek POW. W okresie międzywojennym zawodowy oficer WP w stopniu podpułkownika, walczył w kampanii wrześniowej, następnie żołnierz Armii Krajowej (ppłk „Rój”). W momencie wybuchu powstania warszawskiego pełnił funkcję zastępcy komendanta Obwodu Śródmieście. Zginął w powstaniu 13 września 1944 r. W czasie wojny zginęła trójka jego rodzeństwa: Tadeusz (ppor. rez. w 1940 r. w Charkowie), Czesław i Zdzisława (żołnierze AK, zamordowani przez pułtuskie gestapo 4 września 1944 r.). K. Handke, Wspomnienia. $W$ kepi $i$ w helmie - dzieciństwo i młodość w Pułtusku (1914-1926). Moja wojenna tułaczka (1939-1946), K. Łukawski i K. Wiśniewski (oprac.), Pułtusk 2015, s. 19 i nast.; Charków Księga Cmentarna Polskiego Cmentarza Wojennego, Warszawa 2003, s. 64.

15 Młodzież gromińska wystawiała sztuki Jaśkowe zmysły, Świt, Posiew wolności. Przedstawienia cieszyły się popularnością i grano je po kilka razy.

16 Kupiono dzieła o tematyce patriotycznej (m.in. Sienkiewicza, Orzeszkowej, Konopnickiej, Prusa, Mickiewicza i Słowackiego).

175 Pułk Piechoty Legionów Polskich przybył do Pułtuska 28 listopada 1916 r. i opuścił miasto wiosną kolejnego roku. Jednostką dowodził ppłk Leon Berbecki. J. Szczepański, Ziemia Pułtuska w walce o niepodległość, Pułtusk 1993, s. 24; A. Koseski, J. Szczepański (red.), dz. cyt., s. 210-211.

18 Jednym ze skutków nawiązywania bliższych znajomości między żołnierzami a mieszkańcami (mieszkankami) Pułtuska był ślub Marii Słomińskiej, siostry Franciszka i Wacława, z oficerem legionowym Józefem Beckiem - późniejszym ministrem spraw zagranicznych. 


\section{Rok 1917}

Rok 1917 obfitował w ważne wydarzenia o znaczeniu historycznym i politycznym. W Rosji rewolucja lutowa (12 marca) obala carat i wprowadza rządy burżuazyjno-demokratyczne.

6 kwietnia 1917 r. Stany Zjednoczone Ameryki Północnej przystąpiły do wojny po stronie Ententy.

W związku z odmową złożenia przysięgi przez legionistów na wierność cesarzy Niemiec i Austrii, wiosną 1917 r. zostali internowani w Beniaminowie i Szczypiornie (obozy koncentracyjne).

Z dniem 1 września 1917 r. nauczyciel M. Gałczyński został przeniesiony z Gromina do wsi Grochy, a do Gromina przybyła nauczycielka Janina Zakrzewska (Małecka), która uczyła w chacie p. Stanisława Domżalskiego. Oprócz nauki z dziećmi dziennej prowadziła również kurs wieczorowy z młodzieżą i współpracowała z POW.

Pod okupacją niemiecką młodzież spontanicznie organizowała Koła, które powstawały po wioskach jak przysłowiowe grzyby po deszczu. Dn. 15 października 1917 r., z mojej inicjatywy, zorganizowaliśmy Koło Młodzieży Wiejskiej im. Tadeusza Kościuszki w Grominie, w setną rocznicę Jego śmierci. Prezesem Koła wybrano mnie. Koło przejęło od p. Pańkowskiego biblioteczkę, zaprenumerowało tygodnik PSL „Wyzwolenie” i tyg. „Gazetę Świąteczną”. Miło i pożytecznie spędzaliśmy czas na naszych zebraniach. Była to jedyna szkoła wychowania patriotycznego i obywatelskiego ${ }^{19}$.

7 listopada 1917 r. w Rosji wybuchła Rewolucja socjalistyczna Lenina.

\section{Rok 1918}

Dn. 1 lutego 1918 r. otwarto w Pułtusku przy ul. Kościuszki w domu p. Chodkowskiego szkołę, tzw. Preparandę, dwuletni kurs, przygotowujący kandydatów do pięcioletniego Seminarium Nauczycielskiego ${ }^{20}$.

Egzaminy na I i II kurs preparandy odbyły się w dniach 30 i 31 stycznia 1918 r. Do egzaminu zgłosiło się wiele dziewcząt i chłopców z pow. Pułtuskiego i sąsiednich. Ja zdałem na drugi kurs. Kierownikiem preparandy był prof. Aleksander Makarewicz, prefektem ks. Średziński, polonistką - Felicja Biodrowska i gimnastyk - Fryderyk Plater, który zorganizował z uczniów harcerstwo. W końcu czerwca otrzymaliśmy promocję na pierwszy kurs Seminarium Nauczycielskiego.

19 W latach 1917-1918 w kole działało 46 dziewcząt i chłopców. Odżyja wspomnienia sprzed 50 lat..., „Trybuna Mazowiecka” 1967, nr 245.

20 Stanisław Kotarski zauważył, iż była to pierwsza placówka tego typu w Polsce. Po niej powstały preparandy w Skierniewicach, Chełmie i Zduńskiej Woli. Patrz: S. Kotarski, Szkolnictwo i oświata w Pułtusku, [w:] A. Gieysztor i in. (red.), Pułtusk. Studia i materiały z dziejów miasta i regionu, t. 1, Warszawa 1969, s. 91. Patrz również: J. Doroszewski, Uczniowie Seminariów Nauczycielskich w Polsce w latach 1918-1937, „Przegląd Historyczno-Oświatowy” 2014, 1-2 (223-224), s. 44; T. Kowalski, Preparanda Nauczycielska w Pułtusku w latach 1918-1925, „Rocznik Mazowiecki” 2002, t. 14, s. 85-98. Wspomnienia o nauce w pułtuskiej Preparandzie Nauczycielskiej i Seminarium Nauczycielskim patrz: W. Kocot, Pamiętniki i korespondencja z lat 1920-1939-1945, oprac. R. Lolo, K. Wiśniewski, Pułtusk 2009, s. 54-60. 
3 marca 1918 r. Niemcy i Austria podpisały traktat pokojowy w Brześciu z Rosją Socjalistyczną.

9 maja Niemcy i Austria podpisały pokój z Rumunią w Bukareszcie.

W lipcu na froncie włoskim wojska austriackie poniosły klęskę nad rzeką Pia$w_{a ̨}^{21}$. Na froncie zachodnim, we Francji, Niemcy dostają mocne cięgi. Od 2 września odwrót Niemców na całym froncie zachodnim.

29 września 1918 r. kapitulacja Bułgarii.

Dn. 15 września otwarto pierwszy kurs Seminarium Nauczycielskiego w Pułtusku, obok preparandy, w domu p. Chodkowskiego. Dyrektorem całości był prof. Aleksander Makarewicz. Personel nauczycielski powiększył się o prof. Julię Rosnowską ${ }^{22}$. Mieliśmy dobrych wychowawców i wykładowców. Kochaliśmy ich bardzo. Dobrze i przyjemnie nam się pracowało z nimi.

$\mathrm{Na}$ froncie zachodnim państwa Ententy (koalicja) coraz bardziej naciska na Niemców, którzy stawiają rozpaczliwy opór, lecz zmuszeni są do ciągłego odwrotu. Coraz bardziej pali się grunt pod ich stopami.

Dn. 15 października 1918 r. z rozkazu Komendy POW przecięliśmy wszystkie druty telefoniczne wokół Pułtuska. Przecięcie na wszystkich liniach nastąpiło jednocześnie, tj. o wschodzie księżyca. Ja, Józek Bieliński i Walenty Borek, z sekcji POW Gromin, przecięliśmy druty na słupach telefonicznych przy szosie Pułtusk-Nasielsk, we wsi Kokoszka. Józef Kocięcki ze swymi peowiakami z Przewodowa, przecięli przy szosie Pułtusk-Ciechanów koło wsi Kozłówka. Inne sekcje POW przecięły druty na pozostałych liniach. Ponieważ łączność z Pułtuskiem była przerwana, dlatego następnego dnia od rana krążył samolot nad miastem i koszarami, przeprowadzając zwiad. Zadaniem tej akcji było sprawdzenie sprawności organizacji i wykazania Niemcom, że naród polski jest zorganizowany i gotowy do każdego czynu ${ }^{23}$.

30 października zawieszenie broni z Turcją. Demonstracje i wrzenie antywojenne w państwach centralnych.

3 listopada Austro-Węgry kapitulują i podpisują zawieszenie broni. Bunt marynarzy niemieckich w Kilonii i odmówienie posłuszeństwa.

7 listopada 1918 r. powstał w Lublinie Tymczasowy Rząd Ludowy Republiki Polskiej z premierem Ignacym Daszyńskim, złożony z socjalistów i ludowców, z Wincentym Witosem i Rydzem Śmigłym.

9 listopada 1918 r. proklamowanie republiki w Niemczech. Ucieczka cesarza Wilhelma II do Holandii.

9 listopada (sobota) zebranie członków Koła Młodzieży w Grominie, na którym wybrano nowy Zarząd, złożony z koleżanek, z prezesem Józefą Skarżycką.

\footnotetext{
Autor błędnie podaje miesiąc - bitwa stoczona została w dniach 15-23 czerwca $1918 \mathrm{r}$.

22 Julia Rosnowska (1857-1925), nauczycielka przedmiotów pedagogicznych w Państwowym Seminarium Nauczycielskim w Pułtusku.

${ }^{23}$ W ramach akcji przeprowadzonej w nocy z 14 na 15 października 1918 r. spalono również dwa wiatraki w Wyszkowie i rozlepiono odezwy do ludności polskiej. A. Koseski, J. Szczepański (red.), dz. cyt., s. 213.
} 
Zmiany tej dokonano na skutek wydarzeń zaistniałych w ostatnich dniach. Na zakończenie zebrania postanowiono następnego dnia, tj. 10 listopada 1918 r. udać się do kościoła w Pułtusku, a następnie do fotografa celem dokonania grupowego zdjęcia pamiątkowego członków Koła.

Dn. 10 listopada 1918 r. odbyło się nad ranem ostatnie ćwiczenie POW w lesie szpitalnym koło wsi Płocochowo ${ }^{24}$, pod komendą Józefa Nodzykowskiego, ps. „Mazur”, ze wsi Kacice, zakończone serdecznym uściskiem dłoni ze słowami „Do zobaczenia w wolnej Polsce".

Członkowie Koła Młodzieży w Grominie licznie przybyli do kościoła w Pułtusku i do fotografa, który dokonał zdjęcia grupy.

Po południu tego dnia udałem się do wsi Kacice na zebranie członków Polskiego Stronnictwa Ludowego „Wyzwolenie”, które odbyło się w szkole. Obradowano przy otwartych oknach, za którymi stał tłum ludowców, gdyż sala szkolna, wypełniona po brzegi, nie mieściła wszystkich. Obradowano w nastroju poważnym patriotycznym i w ogromnym podnieceniu, gdyż była to chwila doniosłych wydarzeń na skalę historyczną. Przewodniczyli: Stanisław Deptuła i Piotr Koczara ${ }^{25}$. Zgromadzenie ubezpieczali miejscowi peowiacy.

Między innymi głos zabrał Maksymilian Malinowski, redaktor „Wyzwolenia”. Gdy wspomniał o Tymczasowym Rządzie Ludowym w Lublinie, który potrzebuje poparcia moralnego i materialnego społeczeństwa do wypełnienia swych trudnych obowiązków, chłopi spontanicznie rzucali niemieckie marki na stół prezydialny. Wkrótce urósł stos, że do czapki by się nie zmieścił. Takiego entuzjazmu nie spotyka się. Była to nie lekcja, ale egzamin dojrzałości patriotycznej i obywatelskiej zdany na celująco ${ }^{26}$.

Tego przeżycia nigdy nie zapomnę.

Ponieważ Niemcy w każdej chwili mogli opuścić Pułtusk, wybrano kilku przedstawicieli stronnictwa celem objęcia władzy w powiecie, by zapobiec anarchii. Zebranie przeciągnęło się do późnej nocy. Przenocowałem u kolegi Piotra Prusa w Kacicach.

Rano dnia 11 listopada 1918 r. wędrujemy z kol. Prusem do Seminarium na lekcje. W drodze do Pułtuska dogania nas dorożka i zatrzymuje się. Młodzian jadący w niej pyta: „Skąd i dokąd idziemy?” Odpowiedzieliśmy. On powiedział: „Siadajcie na bryczkę. Podwiozę bo też jadę do Pułtuska. Wiozę pilne rozkazy do Komendy POW. Wczoraj wieczorem wrócił z Magdeburga do Warszawy Józef

24 „Las szpitalny” lub „las klasztorny” to nieużywana obecnie lokalna nazwa lasu oddzielającego Płocochowo od Pułtuska. Należał on do płocochowskich dóbr sióstr św. Wincentego à Paulo prowadzących szpital w Pułtusku - stąd nazwa.

25 Pochodzący z Kacic Stanisław Deptuła i Piotr Koczara byli prowodyrami powstania ruchu ludowego w powiecie pułtuskim. Już w niepodległej Polsce ich drogi się rozeszły: w 1928 r. Piotr Koczara kandydował do Sejmu z listy PSL „Wyzwolenie”, Stanisław Deptuła z listy BBWR. P. Koczara dostał się do Sejmu i objął funkcję wiceprezesa Klubu Sejmowego PSL „Wyzwolenie”. A. Koseski, J. Szczepański (red.), dz. cyt., s. 241-243.

${ }_{26}$ Podczas wiecu zebrano ok. 4 tys. marek. J. Szczepański, Ruch ludowy w powiecie pułtuskim, (do roku 1918), Pułtusk 1989, s 14; A. Koseski i J. Szczepański (red.), dz. cyt., s. 213. 
Piłsudski, owacyjnie witany przez ludność. Warszawa rozbraja Niemców. Entuzjazm ogromny. Warszawa szaleje z radości.”

Młodzieńcem tym, wiozącym rozkazy był student trzeciego roku Akademii Medycznej w Warszawie, Strużyński, rodak z Kacic. Na Placu Teatralnym, obecnie Plac Zjednoczenia, wysiedliśmy i podminowani radosnymi nowinami udaliśmy się do Seminarium.

W tym dniu, o godz. 11:00 Niemcy podpisali zawieszenie broni.

W Seminarium normalny spokój. Lekcja ciągnie się niesamowicie długo. Siedzimy w ławkach jak na rozpalonych węglach. Nareszcie pauza. Wybiegamy na ulicę. Cisza. Ruch normalny. Koniec drugiej lekcji. Wybiegamy na ulicę. Po drugiej stronie ulicy była Szkoła Rolnicza. Uczniowie jej wybiegają z okrzykiem: „Niemców rozbrajają”. Biegniemy do miasta. Ulicą na wysokości parku idzie dwóch chłopców z karabinami. Za nimi w odległości dwudziestu metrów pluton niemieckich żołnierzy z karabinami, a za nimi w odległości dwudziestu metrów sekcja $(1+8)$ naszych peowiaków z karabinami. Dziwnie to wyglądało.

Zaczęło się od zamku pułtuskiego, w którym pracowała powiatowa administracja niemiecka. Dn. 11 listopada 1918 r., szesnastu peowiaków, uczniów starszych klas gimnazjum pod dowództwem Józefa Nodzykowskiego i Franciszka Słomińskiego opanowali zamek i rozbroili administrację niemiecką. W czasie rozbrajania Niemcy wezwali pomocy wojskowej z koszar. Przybył wymieniony wyżej pluton, a widząc, że Polacy nie czynią krzywdy Niemcom nie przejawiali chęci użycia broni. Natomiast zapewniono ich, że jeśli złożą broń bez oporu nic im nie grozi. Po namyśle odeszli do koszar. Ta jednostka naszych, eskortująca pluton niemiecki była jednocześnie ubezpieczeniem i objęła wartę przy koszarach.

Na Placu Teatralnym pilnował porządku, na koniu, komendant żandarmerii peowiackiej, Franciszek Słomiński. Zameldowałem swe przybycie. Rozkazał mi ściągnąć sekcję z Gromina. Za koszarami spotkałem Józefa Bilińskiego. Jechał na rowerze do miasta. Powiedziałem o co chodzi. Zawrócił do Gromina. Przybyli wszyscy. Ja tej nocy pełniłem wartę przy mieszkaniu landrata (obecna siedziba Komisariatu M.O.) w Rynku, a następnie przed domem p. Bochenka przy ulicy Kościuszki, gdzie mieszkał zwierzchnik służby leśnej. Padał deszcz ze śniegiem. Drżałem z zimna.

W nocy z 11 na 12 listopada złożyła broń żandarmeria niemiecka ${ }^{27}$. Garnizon wojsk niemieckich skupił się w koszarach po północnej stronie ulicy ciechanowskiej. Komenda niemiecka uzgadniała warunki kapitulacji z naszą komendą, której siedzibą była „Lutnia”, obok sali teatralnej. Komendantem miasta i wojska naszego był porucznik 5 pp legionów - Zakrocki, piękny brunet.

We wtorek, dn. 12 listopada, o godz. 12:00 wszyscy Niemcy z administracji zebrali się na przystani nad Narwią, skąd pod naszą eskortą, statkiem pasażerskim odjechali do Włocławka. Za okupacji kursował statek pasażerski dla Niemców na trasie Pułtusk-Zegrze.

27 J. Szczepański, Niemieckie wojska okupacyjne w Pułtusku w latach 1915-1918, [w:] J. Szczepański (red.), Pułtusk. Studia i materiały z dziejów miasta i regionu, t. 9, Pułtusk 2011, s. 183. 
Środa 13 listopada 1918 r. wreszcie uzgodniono warunki, wg których Niemcy złożyli broń w kozły na placu koszarowym i o godz. 12:00 byli gotowi do odjazdu. Na ulicy przed koszarami stanęło pięćdziesiąt wozów chłopskich do odwiezienia Niemców. Jako eskorta i ubezpieczenie przybyło nas żołnierzy polskich pięćdziesięciu z bronią. Prócz tego załadowano na wóz pięćdziesiąt karabinów i dwie skrzynki amunicji, które miały służyć Niemcom w razie napadu ludności.

Wszystko odbyło się sprawnie i ruszyliśmy. Gdy dojechaliśmy do wsi Gromin, ludność wyległa na szosę. Moja rodzina również. Poprosiłem o coś ciepłego do okrycia. Podrzucono mi ciepłe, wełniane palto. Zakłócenie porządku nastąpiło na odcinku szosy Przewodowo-Kozłówka. Ludność, która kopała ziemniaki folwarczne okazała się agresywna, a zwłaszcza kobiety gdyż tych było więcej. Podbiegli z motykami i kamieniami złorzecząc Niemcom.

Przed wsią Osiek kolumna się zatrzymała. Niemcy zeszli z wozów i zebrali się na polu. Przemawiał ich komendant i pastor. Podkreślili humanizm i kulturę Polaków. Pieśnią nabożną zakończyli zbiórkę i ruszyliśmy dalej. Chwilowy postój w Gołyminie i w nocy dojechaliśmy do Ciechanowa na nocleg. Po nakarmieniu koni wozy wróciły do Pułtuska wraz z karabinami zarezerwowanymi dla Niemców.

Czwartek, dn. 14 listopada 1918 r. Po spożyciu śniadania odprowadziliśmy Niemców na rampę kolejową w Ciechanowie. Tam przeprowadziliśmy rewizję bagaży. Zabraliśmy kilka rewolwerów i wiele przedmiotów nie stanowiących rzeczy osobistych. To wszystko na dwóch wozach odjechało do Pułtuska. Około południa nadszedł pociąg-węglarka od strony Nasielska i po załadowaniu się odjechaliśmy do Mławy.

W czasie tej jazdy od strony Litwy, torem kolejowym wędrowali jeńcy Rosjanie, wypuszczeni z niewoli niemieckiej. Gdy nadjechaliśmy nad nich, wykorzystali swoją zemstę i obrzucili pociąg kamieniami ze słowami „Germańcy, sukinsyny, miateżniki” ${ }^{28}$. O zmierzchu dojechaliśmy do Mławy. Po pewnym czasie przybyli miejscowi peowiacy i przejęli od nas Niemców pod swoją opiekę, a my odmaszerowaliśmy do miasta Mławy na nocleg.

Następnego dnia tj. w piątek 15 listopada 1918 r. rano po spożyciu śniadania odjechaliśmy z Mławy pociągiem osobowym do Ciechanowa.

Z Ciechanowa do Pułtuska przyjechaliśmy furmankami wieczorem do koszar, w których już kwaterowali nasi chłopcy-żołnierze i mundurowali się z magazynów poniemieckich. My po przyjeździe również.

Wreszcie po pięciu dniach nadludzkiego wysiłku i wyrzeczenia, chłodu, głodu i niedospanych nocy, można było się wyspać i wypocząć we „własnym” kącie, w koszarach na łóżku i pod kocem. Pełniliśmy ofiarnie służbę wojskową dniem i nocą, w pogodę i deszcz, o chłodzie i głodzie. Tego wymagała służba.

Wielu chorowało z przemęczenia i przeziębienia. Peowiak, nauczyciel z Lipnik Starych, Stefan Mackiewicz, zmarł w szpitalu pułtuskim dn. 21 grudnia $1918 \mathrm{r}$. na zapalenie płuc. W eksportacji zwłok wzięła udział kompania wojska, straż

${ }^{28}$ Ros.: „Niemcy, sukinsyny, buntownicy”. 
pożarna z orkiestrą, młodzież i ludność miasta. Został pochowany na cmentarzu św. Krzyża, w grobie rodzinnym z honorami wojskowymi. Podczas opuszczania trumny do mogiły, sekcja wojskowa oddała trzy salwy.

Kolega Józef Kocięcki po podleczeniu w szpitalu wyjechał do rodziny w Przewodowie i po wyzdrowieniu wrócił do Seminarium Nauczycielskiego. Pierwszą wigilię Bożego Narodzenia w wolnej Polsce obchodziliśmy uroczyście i radośnie w kasynie oficerskim. Wieczerzę wigilijną zorganizowała Liga Kobiet pułtuskich tzw. „Ligawki”. Było bardzo przyjemnie i wesoło.

Wszyscy chłopcy Szkoły Rolniczej należeli do POW i po rozbrojeniu Niemców w Pułtusku pozostali w wojsku. Szkołę bez uczniów zamknięto. Dyrektor jej, prof. Pomianowski powiedział: „Jestem szczęśliwy gdyż po wielu latach żmudnej pracy doczekałem żniw i zbieram obfity plon”.

Rok 1919

Zaczęło się szkolenie i służba wartownicza w wojsku. Wyszedł rozkaz, że uczniowie, którzy są w wojsku mogą wrócić do swych szkół celem kontynuowania nauki.

Odwiedziłem Seminarium i prof. Julię Rosnowską. Namawiała mnie, bym wrócił do szkoły, że Polsce są potrzebni nauczyciele, na co odpowiedziałem, że najpierw trzeba wyzwolić Polskę, bo bez Polski nie będzie szkół polskich. Przyznała mi rację, pobłogosławiła i pocałowała jak matka, życząc szczęśliwego powrotu. Pozostałem w wojsku do dnia 11 listopada 1921 r., w którym to dniu zostałem bezterminowo urlopowany celem kontynuowania studiów w Seminarium Nauczycielskim w Pułtusku.

Rok 1921-1926

I znów Seminarium Nauczycielskie w Pułtusku.

W poniedziałek, dn. 14 listopada 1921 r. zgłosiłem się na pierwszy kurs Seminarium Nauczycielskiego w Pułtusku po trzech latach służby wojskowej i zasiadłem na ławie szkolnej obok kolegi Kazimierza Olbrysia, który również jak ja odbył służbę wojskową i przed kilku dniami przybył celem kontynuowania nauki. Kol. Olbryś w 1918 r. był uczniem Seminarium Nauczycielskiego im. Konarskiego w Warszawie, gdzie brał udział w rozbrajaniu Niemców.

Preparanda nadal była w domu p. Chodkowskiego, a Seminarium mieściło się częściowo w domach: Chodkowskiego, Cżulinskiego i Falby (b[yła] Szk[oła] Rolnicza). Dyrektorem Seminarium był prof. Leon Butrymowicz, a wychowawcą I kursu prof. Czesław Karp, który uczył rysunku i prac ręcznych.

Wpadłem w wir szeroko rozbudowującego się życia organizacyjnego o charakterze społeczno-wychowawczym. A więc Bratnia Pomoc Uczniowska, której zadaniem była pomoc biednym uczniom, a tych było wielu. Organizowała festyny z loterią fantową w parku miejskim, które pokaźnie zasilały kasę „Bratniaka”. Opiekunką była prof. Julia Rosnowska. 
Drugą organizacją była Spółdzielnia Uczniowska „Przyszłość” z różnymi wydziałami, obejmująca wszystkich uczniów. Na zebraniach sprawozdawczych bywał p. Franciszek Dąbrowski, instruktor „Społem” w Warszawie. Opiekunka Spółdzielni prof. Antonina Zubelewicz.

Harcerstwo. Drużynowy kol. Tadeusz Nałęcz, a od roku 1923 kol. Stanisław Rzemek. Drużynową drużyny żeńskiej była kol. Irena Ciborowska ${ }^{29}$.

Żywą działalność wykazywało Koło Uczącej się Młodzieży Wiejskiej, która odwiedzał Kazimierz Maj z Zarządu Głównego „Siew” w Warszawie. Aktywistami byli: Józef Kocięcki, Piotr Kaczyński, Szczepan Mitkowski i inni.

Na zebraniu sprawozdawczo-wyborczym, które odbyło się w lutym $1922 \mathrm{r}$. prezesem Koła wybrano mnie. Stanowisko to piastowałem do lutego 1926 r. Koło działało na terenie szkoły i powiatu pułtuskiego. Nawiązało współpracę z Kołami Młodzieży istniejącymi na wioskach i organizowano nowe koła. Wysyłano prelegentów z informacjami. Odbył się tygodniowy kurs dla prezesów kół, po którym odbył się zjazd delegatów kół z powiatu, na którym zorganizowano Powiatowy Związek Młodzieży Wiejskiej. W skład Zarządu weszli: prezes - Wincenty Mossakowski, z-ca Władysław Kaczmarczyk, nauczyciel z Psar, sekretarz Marian Podkowiński, uczeń Seminarium, skarbnik - Stanisław Prus z Kacic, człon. Zarządu: Władysław Trzciński z Grabówca i inni. Zarząd Powiatowy nawiązał ścisłą współpracę ze Szkołą Rolniczą w Golądkowie, której dyrektorem był prof. Muraszko.

Istniały w Seminarium: chór mieszany i orkiestra, pod dyrekcją prof. muzyki i śpiewu Kopczyńskiego, które dawały koncerty w sali teatralnej. Istniał również zespół teatralny, amatorski, który również występował na scenie teatru pułtuskiego. Duszą jego był kol. Lucjan Borowiec ${ }^{30}$. Zginął w Katyniu wraz z kol. Marianem Przychodzkim ${ }^{31}$.

$29 \quad$ II Męska Drużyna Harcerska w Pułtusku powstała w listopadzie 1918 r. z uczniów pierwszego kursu Państwowego Seminarium Nauczycielskiego i drugiego kursu Preparandy Nauczycielskiej. Od lutego 1919 r. nosiła imię Tadeusza Kościuszki. Od 1930 r. (po unifikacji numeracji) nosiła nazwę $11 \mathrm{MDH}$ in. T. Kościuszki. Żeńska Drużyna Harcerska im. Emilii Platerówny przy Państwowym Seminarium Nauczycielskim powstała w 1920 r. P. Rzepiński, $Z$ dziejów pułtuskiego harcerstwa w latach 1912-1948, [w:] J. Szczepański (red.), dz. cyt., t. 5, s. 166-167, 170; T. Kowalski, Z kart pułtuskiego harcerstwa, Pułtusk 1999, s. 6-7; W. Kocot, dz. cyt., s. 60.

30 Lucjan Borowiec (1904-1940), absolwent Państwowego Seminarium Nauczycielskiego w Pułtusku i Państwowego Wyższego Kursu Nauczycielskiego w Poznaniu (1933, śpiew i muzyka), nauczyciel w Szkole Powszechnej nr 3 w Pułtusku. Podporucznik rezerwy WP (starszeństwo 1.01.1930), przydzielony do $13 \mathrm{pp}$. We wrześniu 1939 r. trafił do niewoli sowieckiej do obozu w Kozielsku. Zamordowany w Katyniu wiosną 1940 r. Archiwum Państwowe Obwodu Brzeskiego (Białoruś), Ośrodek Wyszkolenia Rezerw Piechoty w Różanie nad Narwią, Teczka ewidencyjna ppor. Lucjana Borowca, sygn. ВҮ ГАБр ф. 363, д. 36; https://katyn.ipn.gov.pl/kat/ludzie/ofiary/baza-wyszukiwar$\mathrm{ka} / \mathrm{r} 51365, \mathrm{BOROWIEC} . \mathrm{html}$ [dostęp: 4.10.2021].

31 Marian Przygodzki (1902-1940), absolwent Państwowego Seminarium Nauczycielskiego w Pułtusku, nauczyciel i kierownik szkoły w Porządziu. Podporucznik rezerwy WP, w 1939 r. walczył w 13 pp. Trafił do niewoli sowieckiej i przebywał w obozie w Kozielsku. Zamordowany w Katyniu wiosną 1940 r., https://katyn.ipn.gov.pl/kat/ludzie/ofiary/baza-wyszukiwarka/r211540885962,PRZYCHODZKI.html [dostęp: 4.10.2021]; Katyń to było milczenie [wywiad z Marią Bulikowską, córką M. Przygodzkiego], „Tygodnik Ostrołęcki” 2010, 15 sierpnia, https://to.com.pl/katyn-to-bylo-milczenie/ar/6341924 [dostęp: 4.10.2021]. 
Istniały kółka zainteresowań: plastyczne, introligatorskie, fotograficzne, polonistyczne, matematyczne i inne.

Były organizowane uroczyste wieczornice z okolicznościowymi referatami, występami Chóru i orkiestry. Były wieczorki taneczne w sali gimnastycznej. Zabawy karnawałowe, tzw. „Śledzik” w sali „Lutni” z kotylionem, karnecikami, na których bawiono się w różne gry towarzyskie.

Dyrekcja Seminarium przywiązywała dużą wagę wycieczkom krajoznawczym, które były organizowane każdego roku. Całej szkoły, jedno i dwu-dniowe na tzw. „Kurpie”: Obryte, Rząśnik, Gródek, Zambski, Porządzie, „Pulwy”. Klasowe, kilkudniowe do: Krakowa, Łodzi, Katowic, Warszawy, w góry i nad morze, w poznańskie.

Tak pracowicie biegły lata, że często nie było czasu na odrabianie lekcji. Dlatego z wielką uwagą słuchaliśmy i notowaliśmy wykłady lekcyjne, które wystarczały za nabytą wiedzę. Wychowawczynią naszą w latach szkolnych: 1924/25 i 1925/26 była prof. Wanda Grudzińska-Łucznikowa, bardzo lubiana przez uczniów.

Dnia 25 marca 1925 r. zmarła w miejscowym szpitalu ukochana przez wszystkich, prof. Julia Rosnowska, przeżywszy 68 lat. W dniu 28 marca 1925 r. odbyła się eksportacja zwłok na cmentarz miejscowy. Spoczęła w grobie obok mogiły, kopca - pomnika poległych żołnierzy w obronie Polski pod Pułtuskiem w dniach 10 i 11 sierpnia 1920 r. Za okupacji niemieckiej w 1941 r. dokonano ekshumacji zwłok Julii Rosnowskiej i Marii Bloch, siostry b. dyr. Butrymowicza, na cmentarz św. Krzyża w Pułtusku, które złożono do wspólnego grobu. Zajął się tym kol. Franciszek Mimurski oraz kol. Józefa Wąsiewska-Mimurska, ponieważ Niemcy planowali na miejscu cmentarza założyć park.

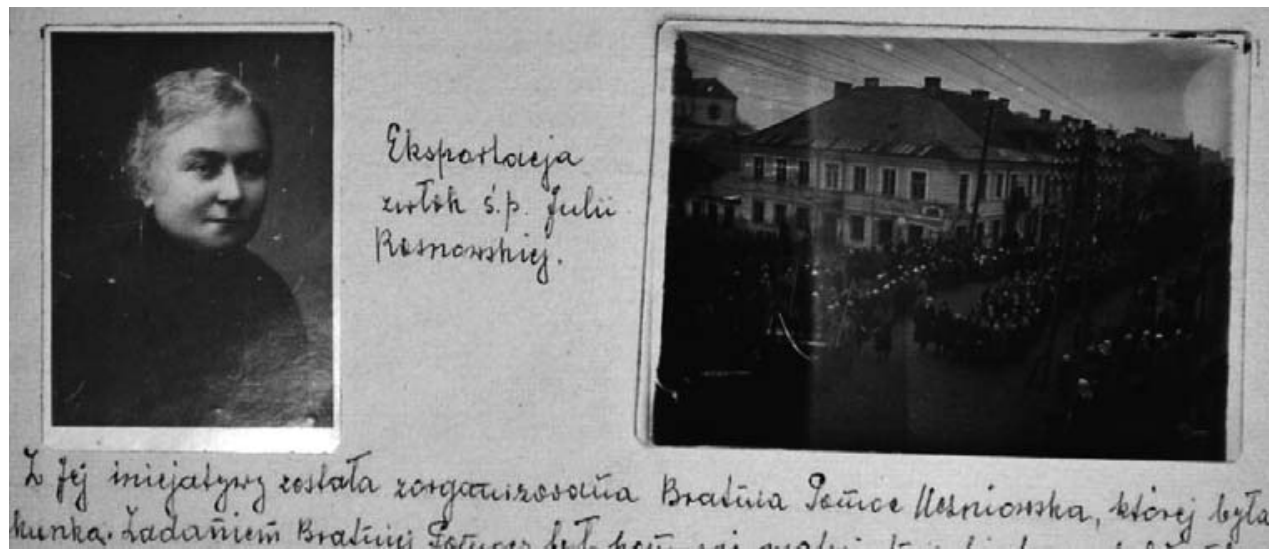

Fot. 2. Julia Rosnowska i zdjęcie z jej pogrzebu (kondukt żałobny przechodzi ulicą 3 Maja)

Źródło: Pułtuska Biblioteka Publiczna im. Joachima Lelewela, Księga pamięci zmarłych, poległych i pomordowanych nauczycieli i nauczycielek z powiatu pułtuskiego od 1918 roku [rkps]. 
I tak przyszła wiosna 1926 roku, a z nią matura z prawem nauczania w szkołach powszechnych. Pierwszą placówką nauczycielską moją była wieś Wólka Lubielska, od sierpnia 1926 r., do grudnia 1927, a od grudnia 1927 r. Leszczydół Stary.

Opracował swe wspomnienia:

Wincenty Mossakowski

\section{BIBLIOGRAFIA}

\section{Archiwalia}

Archiwum Państwowe Obwodu Brzeskiego (Białoruś), Ośrodek Wyszkolenia Rezerw Piechoty w Różanie nad Narwią, Teczka ewidencyjna ppor. Lucjana Borowca, sygn. ВY ГАБр ф. 363, д. 36;

Archiwum Państwowe w Warszawie Oddział w Pułtusku, Akta stanu cywilnego Parafii Rzymskokatolickiej w Przewodowie, Akt urodzenia nr 31/1899 r., sygn. 79/117/0/$/ 39$.

Biblioteka Pedagogiczna Ciechanowie Filia w Pułtusku, Kronika Pedagogicznej Biblioteki Powiatowej w Pułtusku [rkps].

Pułtuska Biblioteka Publiczna im. Joachima Lelewela, Księga pamięci zmarłych, poległych i pomordowanych nauczycieli i nauczycielek z powiatu pułtuskiego od 1918 roku [rkps].

Zbiory Edwarda Malinowskiego z Pułtuska, [Wincenty Mossakowski] Na 60-lecie Preparandy, Seminarium Nauczycielskiego i rozbrojenia Niemców 1918 roku w Pułtusku.

\section{Opracowania}

Charków Księga Cmentarna Polskiego Cmentarza Wojennego, Warszawa 2003.

Doroszewski J., Uczniowie Seminariów Nauczycielskich w Polsce w latach 1918-1937, „Przegląd Historyczno-Oświatowy” 2014, 1-2(223-224).

Handke K., Wspomnienia. W kepi i w hełmie - dzieciństwo i młodość w Pułtusku (19141926). Moja wojenna tułaczka (1939-1946), K. Łukawski, K. Wiśniewski (oprac.), Pułtusk 2015.

Kiljan Z., Tajne nauczanie w latach okupacji, [w:] A. Gieysztor i in. (red.), Pułtusk. Studia i materiały z dziejów miasta i regionu, t. 2, Warszawa 1975.

Kocot W., Pamiętniki i korespondencja z lat 1920-1939-1945, R. Lolo, K. Wiśniewski (oprac.), Pułtusk 2009.

Koseski A., Szczepański J. (red.), Dzieje Pułtuska, t. 2: 1795-1989, Pułtusk 2017.

Kotarski S., Szkolnictwo i oświata w Pułtusku, [w:] A. Gieysztor i in. (red.), Pułtusk. Studia i materiały z dziejów miasta i regionu, t. 1, Warszawa 1969.

Kowalski T., Młodyński J., Szczepański J., Wpisani w historię Pułtuska. Słownik biograficzny, Pułtusk 2001.

Kowalski T., Nauczyciele i młodzież szkolna Pułtuska wobec walki narodu polskiego o niepodległość w latach 1914-1918, „Rocznik Mazowiecki” 2000, nr 12.

Kowalski T., Nauczyciele ziemi puttuskiej w latach wojny i okupacji niemieckiej (19391945): część II, „Rocznik Mazowiecki” 2004, nr 16. 
Kowalski T., Państwowe Seminarium Nauczycielskie w Pułtusku w latach 1918-1938, [w:] H. Samsonowicz i in. (red.), Pułtusk. Studia i materiały z dziejów miasta i regionu, t. 5, Pułtusk 2003.

Kowalski T., Preparanda Nauczycielska w Pułtusku w latach 1918-1925, „Rocznik Mazowiecki” 2002, t. 14.

Kowalski T., Z kart pułtuskiego harcerstwa, Pułtusk 1999.

Odżyja wspomnienia sprzed 50 lat..., „Trybuna Mazowiecka” 1967, nr 254.

Rzepiński P., Z dziejów pułtuskiego harcerstwa w latach 1912-1948, [w:] A. Gieysztor i in. (red.), Pułtusk. Studia i materiały z dziejów miasta i regionu, t. 5, Pułtusk 2003.

Szczepański J.E., Niemieckie wojska okupacyjne w Pułtusku w latach 1915-1918, [w:] J. Szczepański (red.), Pułtusk. Studia i materiały z dziejów miasta i regionu, t. 9, Pułtusk 2011.

Szczepański J., Ruch ludowy w powiecie pułtuskim, (do roku 1918), Pułtusk 1989.

Szczepański J., Ziemia Pułtuska w walce o niepodległość, Pułtusk 1993.

\section{Internet}

https://katyn.ipn.gov.pl/kat/ludzie/ofiary/baza-wyszukiwarka/r211540885962,PRZYCHODZKI.html.

https://katyn.ipn.gov.pl/kat/ludzie/ofiary/baza-wyszukiwarka/r51365,BOROWIEC. html.

Katyń to było milczenie [wywiad z Marią Bulikowską, córką M. Przygodzkiego], „Tygodnik Ostrołęcki” 2010, 15 sierpnia, https://to.com.pl/katyn-to-bylo-milczenie/ ar/6341924.

\section{Memoirs of Wincenty Mossakowski from 1914-1926: Social and Patriotic Youth Activity and Education at the Teachers' College in Pułtusk}

Abstract: The article contains memoirs of Wincenty Mossakowski, an inhabitant of the village of Gromin, near Pultusk, from the first decades of the 20th century. Such memoirs are not often the subject of source publications. According to the author of the article, such reports significantly enrich knowledge about the history of small homelands, especially when they relate to difficult historical periods. It is worth adding that in this case they also enrich knowledge about the history of Mazovia.

Keywords: Gromin, Pułtusk, education, independence, teachers' college, Polish Military Organization 